Témoigner Témoigner. Entre histoire et mémoire

Getuigen Revue pluridisciplinaire de la Fondation Auschwitz

$124 \mid 2017$

La musique dans les camps

Muziek in de vernietigingscentra van

Aktion Reinhardt

La musique dans les centres de mise à mort de L'Aktion Reinhardt

\title{
Bruno Giner
}

Traducteur : Gorik de Henau

\section{(2) OpenEdition \\ Journals}

Édition électronique

URL : https://journals.openedition.org/temoigner/5752

DOI : 10.4000/temoigner.5752

ISSN : 2506-6390

Éditeur :

Éditions du Centre d'études et de documentation Mémoire d'Auschwitz, Éditions Kimé

Édition imprimée

Date de publication : 2 avril 2017

Pagination : 74-87

ISBN : 978-2-930953-00-7

ISSN : 2031-4183

Référence électronique

Bruno Giner, «Muziek in de vernietigingscentra van Aktion Reinhardt», Témoigner. Entre histoire et mémoire [Online], 124 | 2017, Online op 30 novembre 2021, geraadpleegd op 01 décembre 2021. URL: http://journals.openedition.org/temoigner/5752 ; DOI: https://doi.org/10.4000/temoigner.5752 


\section{Muziek in de vernietigingscentra van Aktion Reinhardt} 列 Rilke lezen en 's middags martelen? Of anders uitgedrukt: hoe konden kunst en cultuur bestaan naast moord op industriële schaal? Het is een verschrikkelijke paradox - het falen van elke verlichtingsfilosofie - waruit blijkt dat de mens tot des te meer wreedheid in staat is naarmate hij ontwikkeld is en tot des te meer barbaarsheid naarmate hij beschaafd is.

In de Duitse cultuur en ziel neemt muziek al eeuwenlang een belangrijke plaats in. Daardoor kon het naziregime beter dan wie ook een deel van die glorierijke traditie (Beethoven, Schumann, Brahms, Wagner, Bruckner) ideologisch voor zich opeisen en ermee zwaaien als het schitterende vaandel van 'arische' Germaansheid. Heel wat SS-officieren waren onvervalste muziekliefhebbers: Rödl en Florsted in Buchenwald, Gemmeker in Westerbork, Kramer in Natzweiler-Struthof, Mandel, Mengele en Hößler in Birkenau en Bergen-Belsen enzovoort. Zelfs Reinhard Heydrich, die op systematische wijze 'die Endlösung der europäischen Judenfrage' organiseerde, was een vurig en goed geïnformeerd liefhebber. Hij speelde lang vioo in een strijkkwartet, zijn moeder gaf pianoles, zijn vader was operazanger en werd vervol Geortestad van Georg Friedrich Hândel). Bij zijn begrafenis bewoog de SS-rouwstoet zich voort op het ritme van Siegfrieds Trauermarsch uit Götterdämmerung. Het zijn krachtige symbolen en om je leven te redden kon je een SS'er met muziek vermurwen - de sinistere realiteit van het ontmenselijkte concentratiekampsysteem. Had Joseph Goebbels niet verkondigd dat de Duitsers 'het muzikaalste volk ter wereld' waren? Dit verklaart voor een stuk een zekere tolerantie tegenover verboden muziekgenres en ook het feit dat in 1942 in alle kampen een aantal orkesten, koren en andere muziekformaties officieel werden toegelaten.

Maar de 'onvoorwaardelijke liefde' voor muziek alleen verklaart niet het belang van muzika cactiviteiten in de concentratickampen. Muziek was in de eersteplats en essentieelintrum van propaganda aankwam de Joden te bedriegen in de stations van Betżec, Sobibór en Treblinka. Al snel werd muziek ook gebruikt als instrument van psychologische onderwerping en ontmenselijking, en ging ze dienen om de Arbeitskommandos te tellen die in de pas en in rijen van vijf liepen.

In de meeste kampen hadden musici inderdaad's winters en's zomers als belangrijkste taak elke ochtend dicht bij de toegangspoort te spelen en zo het ritme aan te geven voor wie naar buiten marcheerden om te gaan werken. Elke avond bij de terugkeer gebeurde hetzelfde. De muziek bij dit macabere ritueel ('monsterlijke ritueel', schrijft Primo Levi) was eenvoudig en doeltreffend: Duitse militaire marsen (bijvoorbeeld Alte Kameraden en Ich hatt' einen Kameraden), volksliederen en soms als toppunt van cynisme - vrolijker deuntjes, bijvoorbeeld ouvertures van operettes als toppunt van cynisme - vrolijker deuntjes, bijvoorbeeld ouvertures van operettes
of andere lichte muziek. Volgens Primo Levi symboliseerde die verplichte muziek of andere lichte muziek. Volgens Primo Levi symboliseerde die verplichte muziek
(zowel voor wie haar speelde als voor wie ernaar moest luisteren) het vernietigen van de wil van elke gevangene:

Wanneer die muziek klinkt weten we dat onze kameraden, buiten in de mist, als robots marcheren; hun zielen zijn dood en de muziek drijft hen voort zoals de wind de dorre bladeren en neemt de plaats in van hun wil. Hun wil bestaat niet meer: elke maatslag wordt een stap, een onwillekeurig samentrekken van hun verslapte spieren. Zo ver hebben de Duitsers het gebracht Ze zijn met hun tienduizenden en zijn niet meer do

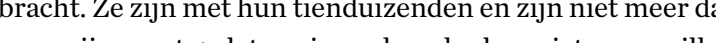
niet, ze marcheren. (Levi 1999, 66)

De orkesten werden verder ingezet bij allerlei officiële 'ceremonies', zoals het bezoek van Reichsführer Himmler aan Auschwitz op 17 juli 1942. Rudolf Vbra herinnert zich het volgende:

Op de stellage verroerde de orkestleider geen vin; hij hield de blik strak gericht op de SS'er bij de toegangspoort die het teken moest geven. Met zijn dirigeerstokje hield hij de muziek tegen, niets anders was voor hem van tel. Dan werd discreet het teken gegeven, Himmler en zijn gevols waren mar twin passen ver meer. Met subtiele gegekwam het stokje in beweging en het gehoorzame, sublieme, kwieke orkest zette een passage uit Aida in, namelijk de Triomfmars.

Muziek werd ook gebruikt voor de persoonlijke ontspanning van SS'ers, kapo's en Blockführer, met concerten op de appelplaats, privéfeestjes, orgieën in de kampbordelen, familiefeesten van SS-officieren en voor de verjaardag van de Führer. In december 1938 in Buchenwald werd het orkest verplicht om een potpourri van walsen te spelen, waarbij de gevangenen in de modder moesten dansen tot ze volledig uitgeput waren. Toen ze een voor een omvielen, werden ze gedwongen om op hun knieën te blijven voortwalsen en als ze weer omvielen, sloegen de schaterlachende SS-bewakers hen dood.

In de meeste kampen kon het orkest of een deel van de musici op elk moment worden opgetrommeld om te spelen tijdens openbare bestraffingen ('uitbetaling' 
in het concentratiekampjargon). Voorbeelden uit Sachsenhausen, Neuengamme, Buchenwald, Mauthausen en Auschwitz I zijn legio. Bernard Duval, die naar Neuengamme werd gedeporteerd, schrijft:

Op de appelplaats vormden de verzamelde gevangen een groot vierkant. In het midden zagen we een primitieve galg, waarvan een touw bungelde vlak boven een krukje. Terwijl we daar strak in de houding stonden, zagen we een orkest aankomen onder leiding van gedeporteerden twee sevansenen volsden met hun handen vatgebon leiding achter de rug. We konden niet geloven dat we hun terechtstelling zouden bijwonen. En
toch... (Duval 2007,153)

Muziek werd tot slot ingezet als propagandamiddel. Esther Bejarano, accordeoniste van het vrouwenorkest in Birkenau (voor ze naar Ravensbrück werd overgebracht), getuigt:

We moesten spelen toen de treinen aankwamen [...]. De gedeporteerden begroetten ons blijmoedig, want ze dachten dat een plek waar muziek werd gespeeld nog niet zo kwaad kon zijn. Dat maakte deel uit van de SS-tactiek.

Inderdaad, tien jaar voor de sinistere transporten naar Birkenau en ruim voor de grote leugen van Theresienstadt was dit de rol die muziek vervulde in de eerste strafkampen van het Reich. In 1933 werd in Oranienburg een korte nieuwsfilm gedraaid. Die neuesten Aufnahmen aus dem Konzentrationslager Oranienburg [De nieuwste opnamen uit het concentratiekamp Oranienburg] had expliciet de bedoeling de publieke opinie en diverse buitenlandse waarnemers te laten zien dat de gevangenen in optimale omstandigheden waren opgesloten en dat ze goed en zonder het minste geweld werden behandeld. Hoe dit beter tonen dan met beelden waarop je een handvol gevangenen ziet zingen met instrumentale begeleiding! Werner Schäfer, de eerste bevelhebber van het kamp, herhaalde zijn leugenachtige propaganda in een publicatie uit 1934, Das Anti-Braunbuch über das erste deutsche Konzentrations een put [Het antibruinboek over het eerste Duitse concentratiekamp]. De voltallige Duitse pers nam er uitgebreide passages uit over en Goebbels' ministerie van Informatie
en Propaganda verdeelde tweeduizend exemplaren.

\section{MUZIEK IN DE KAMPEN VAN AKTION REINHARDT}

Vanaf het begin van operatie Barbarossa in de zomer van 1941 hadden de Einsatzgruppen de opdracht in de Sovjet-Unie de steden en dorpen uit te kammen waa de Panzers van de Wehrmacht net waren gepasseerd. Met pistool en mitrailleur slachtten dezeSS-interventiegroepen de Russischepolitiek commissarissen af nast tienduizend Joods burgers. De 'Holocaust door kogels' zouverschillende maast den duren en leiden tot de dood van meer dan anderhalf miljoen mannen, vrouwen
en kinderen. Hermann Göring gelastte Reinhard Heydrich op 31 juli 1941 met het organiseren en voorbereiden van de Endlösung der europäischen Judenfrage. De maatregelen gingen meteen in: in september vonden in Auschwitz de eerste proeven plaats met $Z y k l o n B$ en vanaf 24 oktober was Joodse emigratie definitief verboden (tussen 1933 en 1941 waren al meer dan een half miljoen Duitse en Oostenrijkse Joden uitgeweken). Voortaan had de Joodse bevolking in de bezette gebieden geen uitweg meer en was ze veroordeeld tot onderduiken, gettovorming en vervolgens tot de dood. Het Poolse Chełmno (vlak bij Łódź) werd het eerste nazivernietigingscentrum. Het was primitief maar luguber doeltreffend, want meer dan 150000 Joden en Roma werden er vergast met koolstofmonoxi van drie speciale vrachtwagens.

Tijdens de interministeriële conferentie van Wannsee, op 20 januari 1942, werden in minder dan twee uur tijd de laatste maatregelen aangaande de Endlösung gepland en goedgekeurd: telling van de Joodse bevolking in de bezette landen (door de Reichs-diensten op elf miljoen geschat), arrestaties, hergroepering in doorgangsgetto's, uitroeiing door arbeid, deportatie naar de uitroeiingscentra in Polen. Het conferentieverslag is veelzeggend:

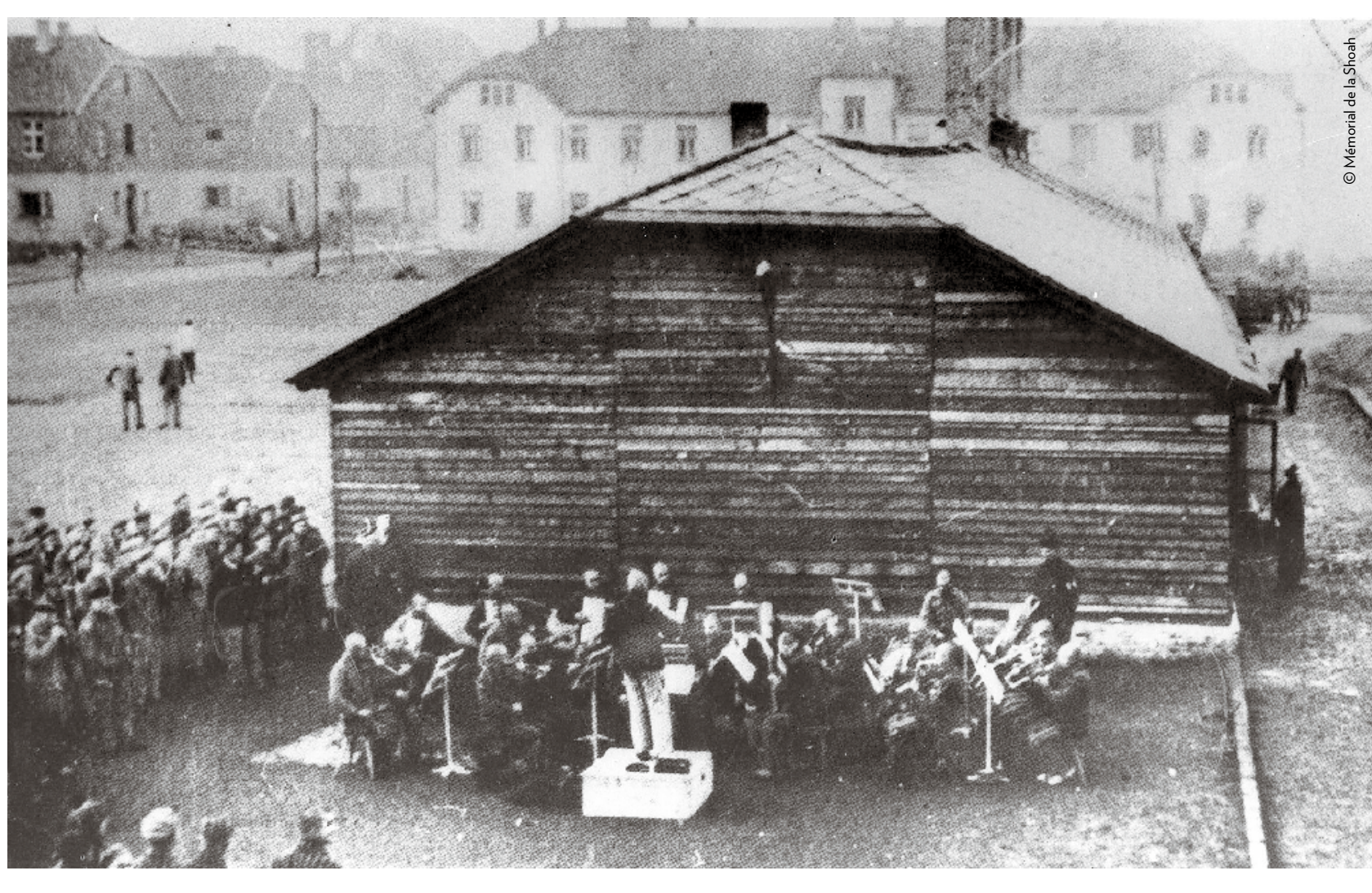


het raam van de Endlösung moeten de Joden worden ingezet als arbeidskrachten in het oosten, in de juiste omstandigheden en met aangepaste voorzieningen. De arbeidsgeschikte Joden zullen worden gehergroepeerd in grote compagnieën, gescheiden naar geslacht en vervolgens naar het oosten gedeporteerd, waarbij ze wegen moeten aanleggen; waarschijnlijk zullen de meesten zo op natuurlijke wijze verdwijnen. De voorraad die bij aankomst overblijft, wellicht met de taaiste elementen, moet op gepaste wijze worden behandeld.

De volledige SS-leiding wist perfect wat 'op gepaste wijze' betekende. Vanaf dat ogenblik werden er steeds meer razzia's gehouden, nu in alle bezette landen. Op 10 ogenblik werden er steeds meer razzia's gehouden, nu in alle bezette landen. Op 10 oktober 1941 keurde de RSHA (Reichssicherheitshauptamt) de ingebruikneming goed van drie nieuwe uitroeiingsscentra met gaskamers. De centra van Aktion Reinhardt,namelijk Bełżec, Sobibór en Treblinka, zouden hun sinistere poorten openen op Pools grondgebied, respectievelijk in maart, april en juli 1942. De SS'ers die in die kampen werkten, waren al bedreven in uitroeiingstechnieken; de meesten waren oudgedienden van Aktion T4, het programma waarmee fysiek en mentaal gehandicapten massaal werden geëlimineerd (tussen januari 1940 en augustus 1941 werden er in zes vergassingscentra meer dan 70000 vermoord). Odilo Globocnik Christian Wirth, Irmfried Eberl, Franz Stangl en Franz Reichleitner waren de belangrijkste WS - ffici SS-officieren belast met de acties van Aktion Reinhardt. Die campagne kan worden beschouwd als de eerste fase in de volledige eliminering van de Joden in het Generalgouvernement, en in mindere mate ook die in Slowakije, Nederland, Duitsland en Frankrijk. Na Chełmno waren Bełżec, Sobibór en Treblinka de eerste vernietigingscentra met gaskamers op basis van koolstofmonoxide.

In maart 1942 werd in Bełżec een begin gemaakt met de massamoorden. Een ruim jaar later, na de opstand van de Arbeitsjuden in Sobibór en Treblinka en ten gevolge van het voltooien van de vier gaskamers in Birkenau, besloot Himmler een einde te maken aan de campagne en er elk spoor van uit te wissen. Dag en nacht zouden tienduizenden lichamen branden in enorme massagraven die de gedeporteerden zelf hadden gegraven. Op 4 november 1943 kon SS-general Odilo Cloboenik zelf had Himmler melden dat de bewuste centra definitief waren venietigd en dat Aktion Reinhardt dus voorbij was. In die eerste vernietigingscentra vonden al bij al vrij weinig muzikale activiteiten plaats, dit in tegenstelling tot Auschwitz-Birkenau. De levensduur was er veel te kort en maar weinig musici leefden langer dan een paar dagen of weken. In die fabrieken van de dood diende muziek vooral een propagandadoel, maar ze werd ook 'ter ontspanning' gebruikt.

$$
\text { BEtŻEC }
$$

Bełżec is een stadje tussen Lwów en Lublin. Het moordcentrum bevond zich op een paar honderd meter van het station en bestreek iets meer dan zeven hectaren. Het belangrijkste centrum bestond uit twee nevenkampen, ten eerste hager I met de houten barakken van de Oekraïense bewakers, de blokken voor de Joden, de werkplaatsen en de ontvangstzone waar de pas aangekomenen zich uitkleedden, en ten tweede Lager II met de gaskamers en massagraven. Zoals vaak woonden de SS-bewakers en -administratie buiten het eigenlijke kamp. Tussen maart en december 1942 werden in de gaskamers van Bełżec tussen de 550000 en 600000 personen (mannen, vrouwen en kinderen) uitgeroeid, hoofdzakelijk Joden, maar ook Roma. Over dit centrum zijn maar twee getuigenissen van overlevenden bekend.

Vooral bij aankomst van de transporten was een orkestje te horen. Het bestond uit een half dozijn amateurmuzikanten (met violen, fluiten en accordeon) en had als uit een half dozijn amateurmuzikanten (metviolen, fluiten en accordeon) en had als belangrijkste taak walsen en andere meeslepende deuntjes te spelen, om zo bij de pas aangekomen gevangenen de illusie te wekken dat het enkel om een doorgangskamp ging. Door dit schandelijke bedrog werd getracht om elke paniek te vermijden. Soms speelde het orkest ook in Lager II, tussen de gaskamers en de massagraven. Dankzij dit orkest konden de SS'ers trouwens ook 'tot rust komen' na de slachtpartijen overdag. De muzikanten werden soms ingeschakeld om nachtelijke drinkgelagen 'op te vrolijken'. In de lente van 1942 werden ze allemaal terechtgesteld en in juni 1943 werd het geheel ontmanteld, vernietigd en gecamoufleerd.

\section{SOBIBÓR}

Sobibór, het tweede centrum van Aktion Reinhardt, begon zijn werkzaamheden op 5 mei 1942. Dit vernietigingscentrum bevond zich dicht bij het dorp Sobibór, in het oostelijke deel van het district Lublin. Het kamp lag op vijf kilometer van de Boeg-rivier, tegenwoordig de grens tussen Polen en Oekraïne. Het centrum was omgeven door bossen en venen, en strekte zich uit over ongeveer 24 hectaren, met drie secties die met prikkeldraad waren afgesloten. Volgens Yitzhak Arad (1987, 462) werden in de gaskamers van Lager III 250000 Joden vermoord, voornamelijk afkomstig uit Polen, maar ook uit Frankrijk, Tsjechoslowakije, Nederland, Litouwen, Duitsland Oostenrijk enzovoort De bevelhebber van het centrum werd bijgestann door een dertigtal SS'ers, op hun beurt seassisteerd door een honderdtal Oekräense door een die door bewakers die de verschillende Arbeitskommandos leidden (in 1942 grensde de streek
rond Sobibór aan het Reichskommissariat Oekraïne).

Zodra de treinen in het station van Sobibór aankwamen, werden de gedeporteerden 'verwelkomd' met muziek uit luidsprekers. Later werd net als in Bełżec een orkestje opgesteld dat speelde terwijl de treinen arriveerden, opnieuw om voor te wenden dat het alleen om een doorgangskamp ging. Op last van de bevelhebber werd in Sobibór ook een koor opgericht dat tijdens de werkmarsen volks- en marsliederen zong (de leider ervan werd trouwens tot kapo gepromoveerd). Hier volgt een voorbeeld, een traditioneel Pools lied (een wals in driekwartsmaat) dat ook in Bełżec werd gezongen: 


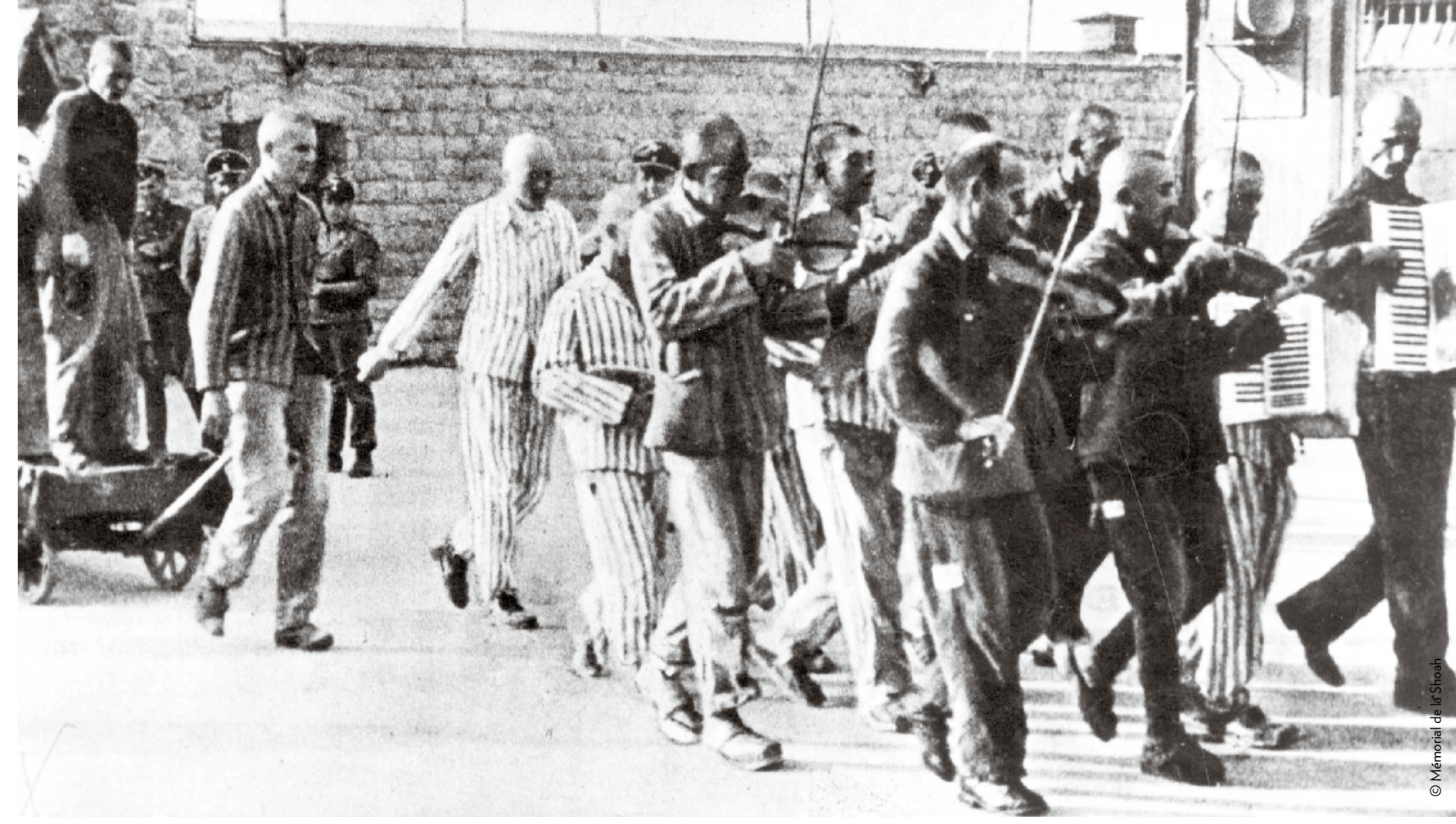

(refrein)

Góralu, wróć się do hal,

y chatach zostali ojcowie;

gdy pójdziesz od nich hen w dal

Bergbewoner, keer terug naar de alpenweiden, naar de hut waar je ouders achterblijven;

(refrein)

wat er intussen van hen zal worden?

Verschillende Joodse beroepsmusici werden gedeporteerd naar en vermoord in Sobibór. We vermelden de Nederlandse componisten Leo Smit en Andries de Rosa allebei in april 1943 gedeporteerd, en Alfred Tokayer, die een maand eerder werd gedeporteerd. Tokayer werd op 23 maart 1900 geboren in Köthen en was dus een exacte tijdgenoot van Kurt Weill. Hij was een leerling van Ernst Toch en werd koorleider en orkestdirigent aan de opera in Bremen. Van 1931 tot 1933 werkte hij voor de Volksoper in Berlijn, waarna hij beroepsverbod kreegopgelegd door de Reichsmusikkammer. Hij ging in ballingschap in Frankrijk, maar na de oorlogsverklaring werd hij als 'onderdaan van een vijandelijke natie' opgesloten in het kamp in Sourioux (departement Cher). Vervolgens trad hij toe tot het vreemdelingenlegioen; zo kon hij het kamp verlaten Verlaten en tegen zijn eighte hij zich in Limoush. La en trachtte Engeland te bereiken. Hij werd samen met zijn vrouw opgepakt bij de demarcatielijn, waarna hij eerst werd opgesloten in Beaune-la-Rolande en daarna in Drancy. In maart 1943 werd hij samen met zijn ouders naar Sobibór gedeporteerd. Alle drie werden ze onmiddellijk naar de gaskamers gestuurd.

Wat het gebruik van muziek als 'ontspanning' betreft, is het getuigenis van de overlevende Kalman Wewerik veelzeggend:

Fahijad

Fahijad

Hoe genoeglijk is het in het groene woud waar ik me neervlij

Fahijad,

Fahijad,

Ik herinner me dat de Duitsers zelfs een huwelijk tussen twee Joodse gevangenen orga-

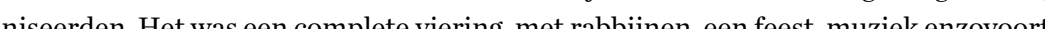
Als hoof olist kozen ze een Joode zanger uit Frankijk. [.] De Duiters huwelijksinzegening opgezet voor hun eigen groteske propaganda. Ze filmden het hele

- Het orkest met gedeporteerden begeleidt een man
naar zijn executie, kamp van 
huwelijk en onmiddellijk daarna werden alle deelnemers, inclusief de Franse solist, afgevoerd naar de gaskamer.

Eind 1943 gaf Himmler het bevel Sobibór om te bouwen tot een simpel concentratiekamp; geen enkele getuige van de uitroeiing mocht in leven blijven. Het gerucht verspreidde zich en op 14 oktober brak een opstand uit. ${ }^{2}$ Meer dan driehonderd gevangenen slaagden erin te ontsnappen, maar voor het kamp definitief werd opgeheven, werden de meesten weer opgepakt en terechtgesteld. Een vijftigtal overleefde de uitbraak. In november 1943 bestond het uitroeiingscentrum Sobibór niet meer. De Wehrmacht demonteerde alle installaties, verbrandde de barakken en blies de gaskamers op.

\section{TREBLINKA}

Op tachtig kilometer van Warschau, dicht bij het dorp Treblinka, werd in jun 1941 het werkkamp Treblinka I opgericht. Nauwelijks twee kilometer verder volgde een jaar later het vernietigingscentrum Treblinka II, 24 hectaren groot en omringd met prikkeldraad en uitkijktorens. Over een periode van bijna elf maanden werden in dertien al 'doucs' jecamoufleerde gaskam bijn 900000 Europe Joden ter dood ge Joden ter dood gebracht (onder wie 250000 uit het getto van Warschau) en ongevee 2000 Roma. Vassili Grossmann, oorlogscorrespondent in het Rode Leger, getuigt:

Om de passagiers uit West-Europa tot op het laatst te misleiden, had het eindpunt va het kopspoor dat uitkwam in het vernietigingskamp het aanzien van een gewoon station gekregen. Op het perron, waar steeds twintig wagons tegelijk werden uitgeladen, stond een stationsgebouw met loketten, er was een bagagekluis, een stationsrestauratie en je zag overal bordjes met pijlen: 'richting Białystok', 'richting Baranowicze', 'richting Wojkowice' enzovoort. In het stationsgebouw speelde een orkestje ter begroeting van aankomende treinen; alle muzikanten waren goed gekleed. (Grossmann 1944)

De musici waren gekleed in, of liever vermomd met, een helwit jasje met blauwe revers en een grote vlinderdas. Ze speelden hoofdzakelijk bij de aankomst van de transporten, tijdens het gevangenenappel en voor het plezier van de beulen.

Het Treblinka-orkest gaf zijn eerste 'concert' op 31 augustus 1942, met een programma van Oekraïense dansen en Joodse muziek. Het werd opgeheven, waarna de Poolse jazzviolist Arthur Gold het in 1943 opnieuw samenstelde. Gold, geboren in 1897, was voor de oorlog violist en orkestleider van het Petersbuski-Goldorkest, een populaire jazzband die bestond uit piano, viool, twee saxofoons, trompet, trombone, banjo en slagwerk. Op het repertoire van dit dansorkest stonden foxtrot, charleston, rumba en tango. Gold werd opgepaktbij razzia's in het getto van Warschau; toen hij in Treblink Treblinka aankwan en meteen a (waarschijnlijk ene Edek, een veertienjarige jongeman), een klarinettist en twee zangers (een man en een vrouw). Arthur Gold en de verschillende leden van zijn orkest werden in 1943 gelijktijdig met de opheffing van het kamp vermoord. Maar afgaand op het getuigenis van Oskar Strawczynski had Gold zich geschikt in zijn relatief 'geprivilegieerde' positie:

Gold vierde zijn veertigste verjaardag met veel uiterlijk vertoon. [...] De zaal was mooi versierd en het orest spelde in geln unform Dehele Duitse en Joodse aristoctie van het kamp had speciale uitnodigingen ontvangen. [...] Gold bereikte het hoogtepunt van zijn speech; hij loofde de Duitsers voor de gunsten die hij ontving en verklaarde dat hij kon begrijpen hoe ze de Joden behandelen, dat dit in het belang van het Duitse volk was. Ik weet niet wat de Duitsers ervan vonden. Ik weet alleen dat Gold vanaf dan voor mij en de meeste anderen zijn charme had verloren, we vertrouwden hem niet meer. We verloren ook ons respect voor zijn artistieke kunnen. (Strawczynski 2007, 127-182; vertaling GdH)

Zoals in veel andere kampen had Treblinka ook zijn eigen lied, namelijk Fester Schritt. Volgens het getuigenis van SS-sergeant Franz Suchomel in de film Shoah van Claude Lanzmann was de tekst van het Treblinkalied geschreven door niemand minder dan de bevelhobber Kurt Franz Als oud-korporaal in Buchenwald wilde Franz de muziek van het Buchenwaldlied gebruiken en de nieuwe tekst werd min of meer op de oorspronkelijke melodie 'geplakt'. Waarschijnlijk was Arthur Gold de auteur van dit arrangement:

\section{Fester Schritt of Treblinkalied}

Fester Schritt und Tritt, und der Blick g'rade aus, Immer mutig und treu, in der Welt geschaut.

Marschieren Kolonen zur Arbeit.

D’rum sind wir in Treblink

Dass unser Schicksal ist ta-ra-ra!

D'rum sind wir in Treblinka

Und gestellt in kurzer Frist.

Wir hören auf den Ton des Kommandanten

Und folgen ihm auf den Winkt

Wir gehen jeden Tritt und Schritt zusammen

Für alles was die Pflicht von uns verlangt.

D’rum sind wir in Treblinka

Dass unser Schicksal ist ta-ra-ra!

D'rum sind wir in Treblinka

Und gestellt in kurzer Frist.

Die Arbeit soll alles hier bedeuten

Und auch Gehorsamkeit un Pflicht

Bis das keine Blick gibt einmal ein Wink. Ho, ha! 
Behalve Arthur Gold werden in Treblinka onder anderen ook deze musici vermoord: de trompettist Adam Furmanski, de violisten Ludwik Holzman, Szymon Pullman en Reuwen Szpilman, de dirigenten Jakub Gladstein en Isaac Zaks.

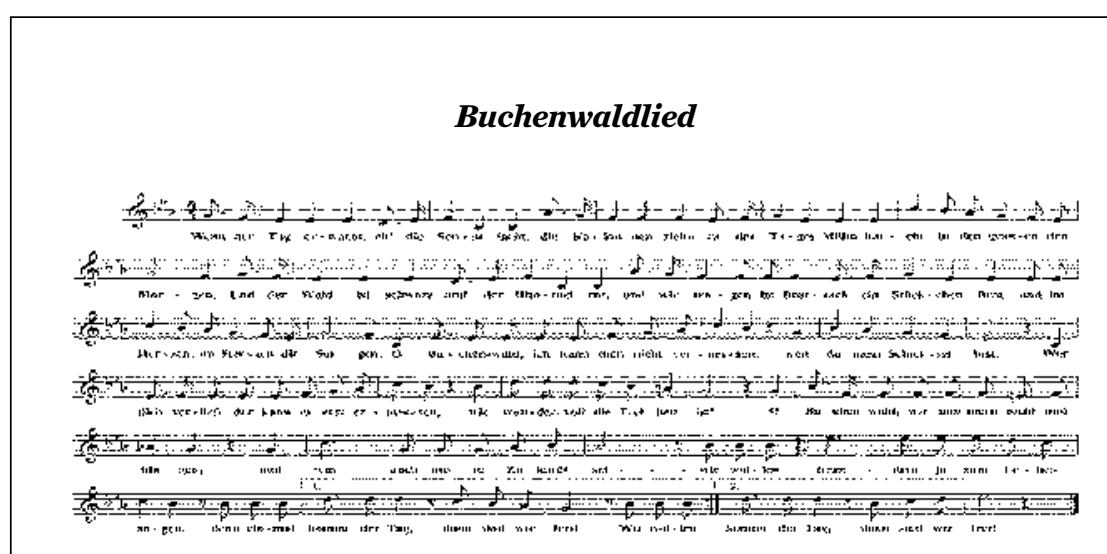

Vanaf het begin van het concentratiekampsysteem zouden de meeste kampen hun eigen lied hebben, naar het voorbeeld van Börgermoor, Sachsenhausen en Dachau. Eind 1938 ontdekte SS-Lagerführer Arthur Rödl, op dat ogenblik in Buchenwald gestationeerd, tot zijn verwondering dat zijn kamp nog geen lied had. Als hartstochtelijk muziekliefhebber organiseerde deze notoire alcoholist een soort wedstrijd voor het beste kamplied. Het vreemde concours werd gewonnen door de componist Hermann Leopoldi (identificatienummer 8454) en de bekende tekstdichter en librettist Fritz Lorner-Beda (identificatienummer 3283). Leopoldi was op 26 april 1938 gearresteerd en werd eerst opgesloten in Dachau, waarna hij naar Buchenwald werd overcebracht Hij was een cabaretart lichte muzen lichte nuzij wak en mars (drie strofen en evenveel refreinen) die het Buchenwaldlagerlied zou worden. Hetlied wed an Röll te hebben geschreven; de twee auteurs waren Joods en het lied maakte dus geen enkele kans om te worden geselecteerd. Natuurlijk werd de winst (tien mark) die aanvankelijk was beloofd nooit uitgereikt, maar Rödl beval dat iedereen het lied meteen moest aanleren. Diezelfde avond nog werden de 7000 gevangenen bijeengebracht op de appelplaats om het lied Block per Block in te studeren, onder wapenstokslagen en bijna vier uur lang.

\section{TOT BESLUIT: MOETEN WE MUZIEK NU HATEN?}

In november 1944 was het 'duizendjarige rijk' de oorlog aan het verliezen. Het Sovjetleger rukte onverbiddelijk op aan het oostfront en de Duitse steden begonnen te kreunen onder de bommen van de geallieerden. Op uitdrukkelijk bevel van Himmler bliezen de SS'ers de verbrandingsovens op in het kamp van Birkenau, verbrandden een groot deel van de documenten en evacueerden tienduizenden gevangenen nar westelijker kampen, meer bepad Buchenwald en darna Bergen-Bes naar westelijker waanzinnige vernietign dichterbij kwam. Tijdens die 'dodenmasen' in het putje van de witer werden de grenzen van het menselijke lijden bereikt en vielen er bijzonder veel slachtoffers. Twee maanden later bevrijdde het Rode Leger het concentratiekampcomplex Auschwitz. De meeste overlevenden waren Prominenten en gevangenen wier arbeid onontbeerlijk was voor het dagelijks functioneren van het kamp. Je had er medische beroepen, een aantal ambachtslui (kleermaker, timmerman, schoenmaker, horlogemaker en kok), maar ook... musici. Pierre Saint Macary, die in Mauthausen werd geïnterneerd, schrijft:

Een jongeman speelt viool, heel goed lijkt me, maar ik ken niet zo veel van klassieke muziek. Ze zeggen dat de violist een Hongaarse Jood en een beroepsmusicus is Waar komt het instrument vandaan? Vanwaar heeft die virtuoos het privilege, tegenover zovele anderen die samen met hem zijn aangekomen en onderaan de ladder zijn gebleven, het plebs van het plebs? Wie heeft dit recital georganiseerd? (Saint Macary 2004, 55)

De vragen zijn relevant, maar alle gedeporteerden wisten dat muziek vooral de $\mathrm{SS}$ ten goede kwam. Iedereen wist ook dat musici minder slecht behandeld werden dan anderen, dat ze in de concentratiekamphiërarchie een relatief 'bevoorrechte' positie innamen en dat ze daardoor een hogere levensverwachting hadden. Daarvoor betalden ze een prijs, namelijk dat ze in de ogen van de andere gedeporterden betallen 'collaborateurs' werden in dienst van de naz's - voor de muscidie de kampen des doods overleefden een positie die ze maar moeilijk konden aanvaarden, zelfs jaren later. Maar had dat handvol bevoorrechten' dan werkelijk een keuze tussen sterven of vioolspelen? Die vreselijke paradox maakte zelf deel uit van het ontmenselijkingsproces.

In bepaalde kampen schrokken gevangenen er niet voor terug om de musici uit te schelden of hun modder in het gezicht te werpen. Pelagia Lewinska, een Poolse gedetineerde in het vrouwenkamp in Birkenau, schrijf:

De stoet trekt voorbij op de maat van een lichte marsmelodie; mensen slepen zich voort (lijken van hun lotgenoten. Hoe haatten we de muziek! (Lewinska 1966, 94; vertaling GdH) 
Inderdaad, hoe geen haat koesteren tegen muziek op SS-bevel? Hoe geen haat koesteren tegen muziek waarmee werd getracht mannen en vrouwen te misleiden die uitgeput waren en op hun laatste benen liepen, op weg naar de gaskamers? Hoe geen haat koesteren tegen muziek die alleen werd gespeeld om de beulen te plezieren? Hoe geen haat koesteren tegen muziek die martelingen en executies

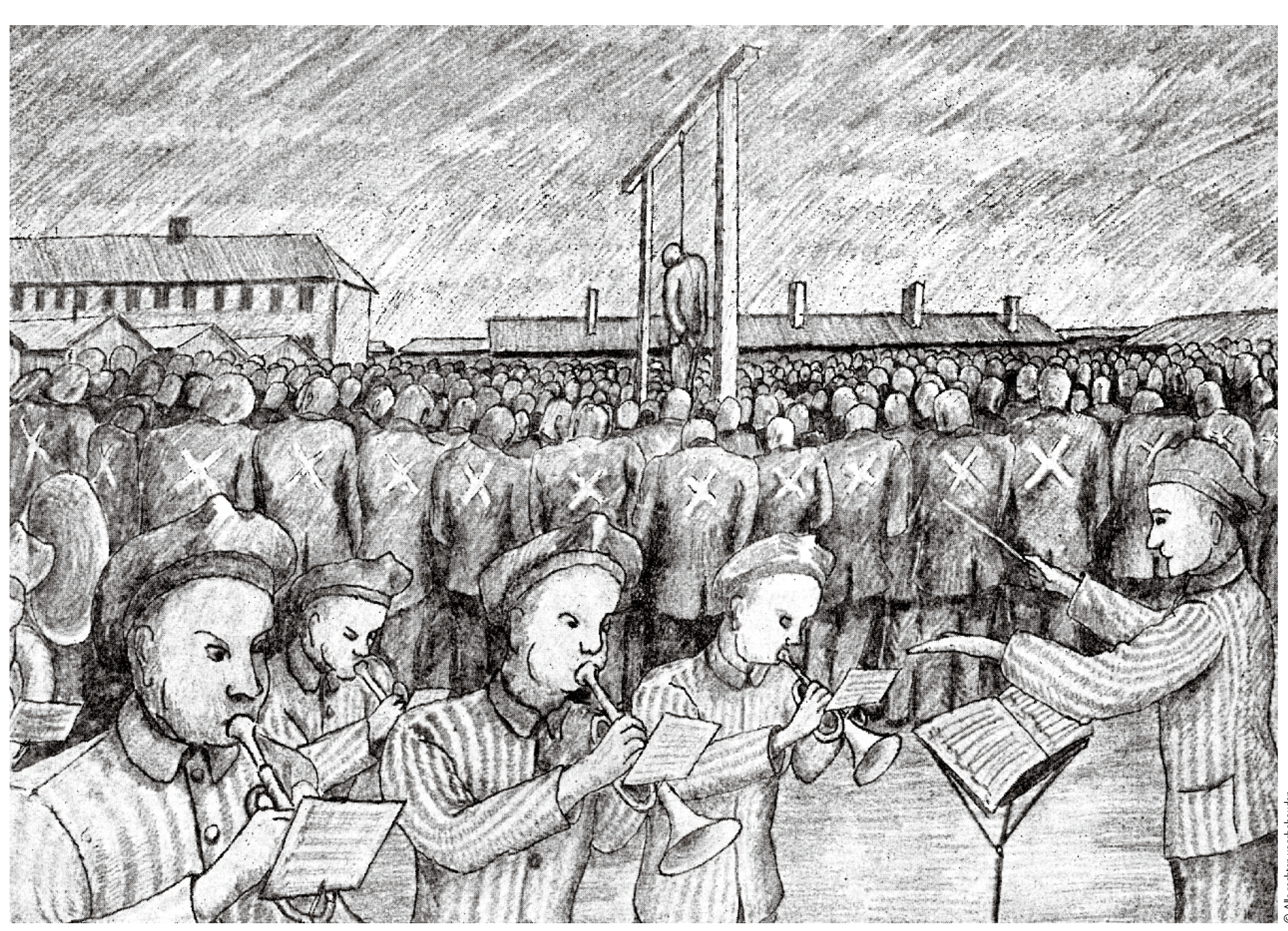

begeleidde? Hoe geen hat koesteren tegen muziek waarmee op sterven na dode arbeidscommando's in het gareel werden gehouden?

Maar de muziek van Bruckner, Wagner en Strauss, is die dan verfoeilijk? Zijn Beethoven, Schubert en Schumann verfoeilijk? Zijn Duitse, Poolse en Russische volksliedjes verfoeilijk? Zijn de strijkkwartetten van Dvoř́k en Mozart verfoeilijk? Zijn salonmuziek, operette en jazz verfoeilijk? Nee, natuurlijk niet. Niet de muziek is verfoeilijk, nae , wat de barbaarse nazi's ermee uit-
richtten.

In zijn roman La haine de la musique schreef Pascal Quignard: 'Muziek is de enige kunstvorm die heeft meegewerkt aan de door de Duitsers ondernomen uitroeiing van de Joden tussen 1933 en 1945. (Quignard 1996, 197; vertaling GdH) Misschien ware het correcter te schrijven: 'Muziek is de enige kunstvorm die tussen 1933 en 1945 met voorbedachten rade door de nazi's werd gebruikt om de Joden uit te roeien.'

BIBLIOGRAFIE

- Yitzhak Arad, Belzec, Sobibor, Treblinka: The Operation Reinhard Death Camps .

- Robert Cahen, Témoignage écrit, Parijs: Association française Buchenwald, Dora et

. Une jeunesse volée J'avais 19 ans en 1944, Nonant. OREP, 2007 - Vassili Grossmann, 'De hel van Treblinka' in Een Klein leven [1944], Amsterdan

- Simon Laks, Mélodies d'Auschwitz, Parijs: Cerf, 2004

- Primo Levi, Is dit een mens [1947], Amsterdam: Meulenhoff, 1999.

- Pelagia Lewinska, Vingt mois à Auschwitz, Parijs: Nagel, 1966.

- Pascal Quignard, La haine de la musique, Parijs: Calmann-Lévy, 1996.

- Pierre Saint Macary, Mauthausen: percer loubli, Parijs: LHarmattan, 2004.

- Oskar Strawczynskki, 'Ten Months in Treblinka' in Isräl Cymlich \& Oskar Strawczynski
(red.). Escaping Hell in Treblinka, New York-Jeruzalem: Yad Vashem, 2008. 